\title{
COMMENT
}

\section{MARITIME LIMITATIONS OF LIABILITY: A STUDY IN CONFLICT OF LAWS}

\begin{abstract}
Trabitronally, foreign limitations of shipowner's liability have been held inapplicable in American courts. ${ }^{1}$ The courts characterize the American limitation statute as procedural, thereby invoking the venerable choice-of-law rule that the lex fori governs in matters of procedure, though foreign substantive law is used. ${ }^{2}$ The facile generality of this rule obscures, however, a complex situation. In addition to the difficulty of distinguishing between substance and procedure, ${ }^{3}$ the "black letter" rule inexorably requires the specified result despite possible rational grounds for applying foreign limitation law. Critics of this rule generally suggest that limitations of liability are substantive rather than procedural, and that, therefore, the lex loci should govern. ${ }^{4}$ A contro-
\end{abstract}

\footnotetext{
${ }^{2}$ Oceanic Steam Navigation Co. v. Mellor (The Titanic), 233 U.S. 718 (1914); Kloeckner Rederei und Kohlenhandel, G.M.B.H. v. A/S Hakedal, 210 F.2d 754 (2d Cir.), cert. denied, 348 U.S. 801 (1954). "Furthermore, on the theory that the limitation law is procedural rather than substantive, so that, on received principles of the conflict of laws, the law of the forum should govern, it has been assumed that American courts will apply American limitation law in any limitation proceedings properly before them." GILMORE \& BLACK, ADMIRALTY 736 (1957) [hereinafter cited as GILMORE \& BLACK]. "The limitation of liability in a maritime cause of action is determined by the law of the forum, irrespective of the law which created the cause of action." RESTATEMENT, Conflict of LaWs $\$ 4$ II (1934).

${ }^{2}$ See generally Beale, The Conflict of Laws $\$ 413.1$ (1935); Goodruch, The CONFLICT OF LAWS 226-28 (3d ed. 3949).

"Cf. Cook, "Substance" and "Procedure" in the Conflict of Laws, 42 YALE L.J. 333 (1933).

'Comment, Limitation of Shipowners' Liability: Substance or Procedure?, 17 U. ChI. L. REv. 388, 393 (1950). "The Court's ruling [in The Titanic] on the limitation point has always been a matter of some doubt. ..." Knauth, Renvoi and Other Conflicts Problens int Transportation Law, 49 ColUM. L. REV I, 4 (1949); Kuhn, International Aspects of The Titanic Case, 9 AM. J. INT"L L. 336 (1915). "[L] [imitation of liability should be applied as the substantive law of the locus delicti in all cases, and in order to determine whether limitation of liability is to be granted, the petitioner must show that by the lex loci delicti he is entitled to limitation. Then, if he is so entitled, the statute of that jurisdiction, if proved, and not the United States Statute, should be applied." Note, Limitation of Shipowners Liability in American Courts, 78 U. PA. L. REV. 393, 400 (1930).
} 
versial 1949 Supreme Court decision arguably lends support to this proposition. ${ }^{5}$

In recent years, a number of important decisions and commentaries have re-examined the whole structure of choice-of-law problems. ${ }^{\circ}$ These modern authorities suggest a new approach to the solution of choice-oflaw problems which would avoid the frequently esoteric substantiveprocedural dichotomy and instead inquire into whether the forum state has sufficient interest in the litigation to warrant application of its law. The traditional choice-of-law rules regarding limitation of liability should be re-evaluated in light of this suggested method.

\section{Development of Limitation LaW}

The Limitation of Liability Act was first enacted in the United States in 185 I as a "Bill to limit the liability of shipowners. . .." The statute was not unique when enacted; such provisions, common in other maritime countries, had put American shipping at a competitive disadvantage. ${ }^{8}$ This inequality, the hazards of ocean commerce, and the inability of the shorebased owner to control the actions of captain and crew while they were at sea, provided the rationale of limitation of liability. 9 The act currently provides in part that:

The liability of the owner of any vessel, whether American or foreign, for any embezzlement, loss, or destruction by any person of any property, goods, or merchandise shipped or put on board of such vessel, or for any loss, damage, ... or forfeiture, done, occasioned, or incurred, without the privity or knowledge of such owner or owners, shall not, except in the cases provided for in subsection (b) of this section [dealing with loss of life], exceed the amount or

${ }^{8}$ Black Diamond S.S. Corp. v. Robert Stewart \& Sons (The Norwalk Victory), 336 U.S. 386 (1949).

- See, e.g., Bernkrant v. Fowler, - Cal. 2d -, 12 Cal. Rptr. 266, 360 P.2d 906 (1961); Schmidt v. Driscoll Hotel, Inc., 249 Minn. 376, 82 N.W.2d 365 (1957), Currie, Married Women's Contracts: A Study in Conflict-of-Laws Methods, 25 U. CH1. L. REv, 227 (1958); Currie, On the Displacement of the Law of the Forum, 58 Colum. L. Rev. 964 (1958); Ehrenzweig, Choice of Law: Current Doctrine and "True Rules," 49 CALIF. L. Rev. 240 (1961); Yntema, The Objectives of Private International Law, 35 CAN. BAR REv. 721 (x957).

${ }^{7}$ Act of March 3, 1851 (Bill to limit the liability of shipowners and for other purposes) ch. $43, \S_{3}, 9$ Stat. 635 . This act is currently cited as Limited Liability Act, REv. STAT. $\$ 4283$ (1875), 46 U.S.C. $\$ 183$ (1958).

${ }^{8}$ GILMORE \& BLACK $663-64$.

'Id. at 696 . 
value of the interest of such owner in such vessel, and her freight then pending. ${ }^{10}$

Before a 1936 amendment, the act had merely specified that the owner of "any ship or vessel" might petition for limitation of liability under its provisions. ${ }^{11}$ As a result, the earliest cases construing that statute were principally concerned with whether foreign shipowners could avail themselves of the American limitation proceeding at all, and not with the possible application of foreign limitations in domestic suits. As early as 1876 the Circuit Court for the Southern District of New York in Levinson v. Oceanic Steam Navigation Co., ${ }^{12}$ held that the act was applicable to foreign vessels, simply stating that "the statute was not in terms confined to American vessels."13 Doubt as to whether a foreign vessel involved in a collision outside the territorial waters of the United States could petition for limitation under the act lingered, ${ }^{14}$ however, until, in $I 88 \mathrm{I}$, the question was presented to the Supreme Court in The Scotland.15 That case involved a suit against a foreign shipowner in the United States courts growing out of a collision on the high seas between an American and a British vessel. Under such circumstances, the Court regarded the law of the forum as generally applicable, ${ }^{18}$ and also held that the foreign respondent could avail itself

${ }^{10}$ Limited Liability Act, Rev. STat. $\$ 4283$ (1875), 46 U.S.C. $\$ 183$ (a) (1958). (Emphasis added.) Section $I 83$ (b) provides that: "In the case of any seagoing vessel, if the amount of the owner's liability as limited under subsection (a) of this section is insufficient to pay all losses in full, and the portion of such amount applicable to the payment of losses in respect of loss of life or bodily injury is less than $\$ 60$ per ton of such vessel's tonnage, such portion shall be increased to an amount equal to $\$ 60$ per ton, to be available only for the payment of losses in respect of loss of life or bodily injury. If such portion so increased is insufficient to pay such losses in full, they shall be paid therefrom in proportion to their respective amounts." Sections $I 8_{3}(\mathrm{c}), 18_{3}(\mathrm{~d})$, $18_{3}(e)$, and $I 8_{3}(f)$, respectively define tonnage, liability on distinct occasions, knowledge of the owners, and seagoing vessels. Limited Liability Act, REv. STAT. \$4285 (1875), 46 U.S.C. $\$ 185$ (1958) deals with procedural requirements under the act.

${ }^{11}$ Act of March 3, I85 I (Bill to limit the liability of shipowners and for other purposes) ch. $43, \S_{3}, 9$ Stat. 635 .

12 I5 Fed. Cas. 422 (No. 8292) (C.C.N.Y. 1876).

${ }^{18} I^{1}$. at 423 .

1" E.g., Churchill v. The British America, 5 Fed. Cas. 676 (No. 2715) (E.D.N.Y. 1878). "[T] $[$ he [limitation] of the United States ... has no extra-territorial effect and cannot be resorted to for the purpose of limiting the liability of a foreigner for a collision occurring on the high seas and beyond the territorial limits of the United States." Id. at 677 .
${ }^{15}$ 105 U.S. 24 (1881).
10 "If they [ships colliding on the high seas] belonged to different nations, having 
of the American limitation proceeding. ${ }^{17}$ The issue in The Scotland was subsequently resolved by Congress in the 1936 amendment to the act which, in broad terms, provides that any vessel "whether American or foreign," ${ }^{18}$ can petition for limitation under its terms.

The Court in The Scotland had further said, by way of dictum, that "[I]f a collision should occur in British waters, at least between British ships, and the mjured party should seek relief in our courts, we would administer justice according to the British limitation law. ..."19 This situation was not, however, considered until 1894 in The State of Virginia. ${ }^{20}$ In that case, suit was brought against British owners by British and American underwriters for cargo lost when the vessel ran aground in British waters. The vessel was a total loss and thus the question was raised whether the higher British limitation law or the lower American act should be applied. ${ }^{21}$ Judge Benedict, citing no authority, wrote: "I have given it due consideration; and my opinion is that the extent of the liability of the shipowner, in a case like this, is determined by the statutes of the United States, and not by the laws of Great Britain."22 The question was not presented to the Supreme

different laws, since it would be unjust to apply the laws of either to the exclusion of the other, the law of the forum, that is, the maritime law as received and practiced therein, would properly furnish the rule of decision." II. at 30 .

${ }^{17}$ "We see no reason, in the absence of any different law governing the case, why it should not be applied to foreign ships as well as to our own, whenever the parties choose to resort to our courts for redress." Id. at $3 \mathrm{x}$. The Court's indiscriminate use of the words "parties choose" implies that the petitioner or the claimants could initiate suit in American courts. This, of course, does not respect practicality, for the shipowner will petition for limitation of liability in the forum the claimants have chosen. See on the limitation point, La Bourgogne, 210 U.S. 95 (1908); The Princess Sophia, 6x F.2d 339 (9th Cir. 1932); Petition of Canadian Pac. Ry., 278 Fed. $x 80$ (W.D. Wash. 1921 ). Cf. Lauritzen v. Larsen, 345 U.S. 57 (1953). "It is pointed out that our statute on limitations of shipowner's liability which formerly applied in terms to 'any vessel' was applied by our courts to foreign causes [citing The Scotland and The Titaric]." Id. at 591 .

${ }_{18}$ Act of June 5, 1936, ch. $52 x, \S 4283(2), 49$ Stat. $x 479$.

19 105 U.S. 24, 29 (1881). This statement was, of course, dictum, since the issue was whether the foreign shipowner could petition for limitation of liability under the American act.

${ }^{20} 60$ Fed. 1018 (E.D.N.Y. 1894 ).

${ }^{21}$ The vessel was a total loss. Therefore, only under the American act, there would be recovery to the extent of the freight then pending. Under the British act, however, claimants could have recovered up to $f 8$ per ton gross registered tonnage. Master's report, The State of Virginia, ibid.

${ }^{22}$ Ibid. This decision thus avoided a determination of whether American or British substantive law governed other aspects of the case, since in no event could there be recovery. 
Court until 1913 in The Titanic, ${ }^{23}$ a case rising out of the well-known collision between the British luxury liner and an iceberg in the North Atlantic. The owners of the vessel, seeking to limit their liability, contended that the American, and not the British, limitation law should govern. The district court, following the dictum in The Scotland, ${ }^{24}$ felt that such a situation required the application of British substantive law. ${ }^{25}$ Moreover, the judge felt that Congress had not intended to favor British shipowners by the act, ${ }^{28}$ and that British limitation law was substantive and "affects a right." The Supreme Court, in a rather surprising opinion, reversed. Mr. Justice Holmes, speaking for a majority of the Court, held that even though British substantive law was generally applicable, the American limitation act should apply. In the most significant portion of the opinion he wrote:

It is true that the foundation for a recovery upon a British tort is an obligation created by British law. But it is also true that the laws of the forum may decline altogether to enforce that obligation on the ground that it is contrary to the domestic policy, or may decline to enforce it except within such limits as it may impose. [Citations omitted.] It is competent, therefore, to Congress, to enact that, in certain matters belonging to admiralty jurisdictions, parties resorting to our courts shall recover only to such extent or in such way as it may mark out. ${ }^{28}$

The Court apparently felt that the American act evidenced a distinct policy to apply the domestic law in all cases before a domestic court even when the petitioner was a foreign shipowner. ${ }^{29}$ It is not clear, however,

\footnotetext{
${ }^{23}$ Oceanic Steam Navigation Co. v. Mellor, 233 U.S. 718 (1914). This decision is commonly referred to as The Titanic, and will be so referred to in this article.

${ }^{24} 209$ Fed. 501, 512 (S.D.N.Y. 1913).

${ }^{28}$ "In this case the collision was between the Titanic and an iceberg, but I can see no reason for a different application of the rule [liability determined by the law of the country to which the ships belong] in a case where a vessel is injured by collision with some floating object belonging to no country, or where a vessel founders on the high seas without any appreciable cause, than in the case of injuries occasioned by the collision of two vessels [On the high seas] of the same nation." 209 Fed. 501, 508-09 (S.D.N.Y. 1933 ).

${ }^{20}$ "There certainly can be no presumption that the object of Congress in passing the ... act limiting the liability of shipowners, was to favor British shipowners." Id. at 510.

${ }^{27}$ "But the statute limiting the liabilities of shipowners is a statute which affects a right." Id. at 509.

${ }^{28}{ }_{233}$ U.S. $7 \times 8,732-34$ (1914). (Emphasis added.)

${ }^{20}$ c'This statute [Limited Liability Act] well might be held to announce a general policy, governing both obligations that arise within the jurisdiction and suits that are brought in the courts of the United States." Id. at 733., See, for similar results, Ferneau
} 
that Congress intended to enunciate any such policy, and in fact, $\mathrm{Mr}$. Justice McKenna dissented on this point, urging that "it [is] a proper deduction from The Scotland that the law of the foreign country should be enforced in respect of the amount of the owner's liability."30

The Titanic was subsequently interpreted by the lower federal courts to mean that foreign limitations of liability were always procedural in nature and that the American limitation should apply. ${ }^{31}$ In reality, however, The Titanic seemed to be based primarily on public policy considerations rather than the substantive-procedural dichotomy. ${ }^{\mathbf{3 2}}$ The interpretation adopted by the lower courts perhaps indicates a judicial desire for predictability and a convenient formula for the decision of cases. It may also be that the lower courts were confused by Holmes's failure to state definitively the policy that lay behind the decision. ${ }^{33}$

In 1949, the Supreme Court reconsidered the question, although not squarely, in The Norwalk Victory. ${ }^{34}$ There, American and British vessels collided in Belgian waters, thus in the Court's view warranting a general application of Belgian substantive law. The cargo owners brought suit in the Eastern District of New York against the owners of the American vessel. The respondents petitioned for limitation of liability and offered to post bond equal to the lower Belgian

v. Armour \& Co., 303 S.W.2d I6I (Mo. Ct. App. I957); Associates Discount Corp. v. McKinney, 230 N.C. 727, 55 S.E.2d-513 (1949); RESTATEMENT, CoNfLict of LAWS $\S 612$ (I934).

${ }^{30} 233$ U.S. 718, 734 (1914).

${ }^{31}$ In Royal Mail Steam Packet Co. v. Companhia de Navegaco Lloyd Brasileiro, 32 F.2d 757 (E.D.N.Y. 1928), a British ship had collided with a Brazilian ship in Belgian territorial waters. The district court held that the domestic limitation act should apply despite the general application of Belgian substantive law of proportional liability and the lack of American interest in the controversy other than the bringing of suit in a domestic court. Similarly, The Titanic holding was followed in The Mardu, 102 F.2d 459 (2d Cir. 1939), which involved the collision of German and Brazilian vessels in Brazilian waters. There, the Second Circuit held that the American limitation applied simply because "statutes permitting limitation are regarded as relating to remedy. ..." Id. at 463 .

${ }^{32}$ See text accompanying notes 27 \& 28 , supra.

${ }^{83}$ For example, "the laws of the forum may decline altogether to enforce that obligation on the ground that it is contrary to the domestic policy, or may decline to enforce it except within such limits as it may impose." 233 U.S. 718, 732 (1914). (Emphasis added.)

${ }_{83}$ Black Diamond S.S. Co. v. Robert Stewart \& Sons, 336 U.S. 386 (1949). It should be noted that The Norwalk Victory was decided after the 1936 change of language in the Limitation of Liability Act. 
amount ${ }^{35}$ in order that the vessel might be released..$^{36}$ The district court dismissed the respondent's petition on the ground that limitation of liability is governed by the law of the forum and, therefore, the bond would have to equal the amount for which petitioners would be liable under American law. ${ }^{37}$

The Norwalk Victory thus presented the converse of The Titanic situation, where the American limitation amount was lower than the foreign. This distinction is the elusive key to Mr. Justice Frankfurter's majority opinion which held that if the limitation of liability was substantive and a limitation of the right under Belgian law, it would be an enlargement of the Belgian-created right to apply the higher American limitation. ${ }^{38}$.The opinion intimates that The Titanic may well have been correct in not applying foreign limitations which were higher than the American and which thus may have been violative of congressional policy toward shipping. ${ }^{39}$ In the exact language of the majority opinion:

[W] hether [there] are in fact considerations of domestic policy which deserve to be measured against application of the lex loci delicti and whether such considerations are as significant where the foreign limitation is lower than our own as where it is higher-these two are questions not now before us in view of the fact that the case is here merely on exceptions to the petition for limitation of liability. ${ }^{40}$

The inference might be drawn from dictum and implications of The Norwalk Victory that in an appropriate situation for application

${ }^{85}$ The American limitation amount was about $\$ \mathrm{r}, 000,000$ in this situation, whereas the Belgian was $\$ 325,000$. The petitioner initially offered to post only the latter amount. See generally GILMORE \& BLACK 736.

${ }^{86}$ Limited Liability Act, REv. STAT. $\$ 4285$ (1875), 46 U.S.C. $\S$ 183 (b) (1958). For the text of this section, see note I0, supra.

${ }^{87}$ See United States v. Robert Stewart \& Sons Ltd., r67 F.2d 308 (2d Cir. 1948).

${ }^{88}$ Black Diamond S.S. Corp. v. Robert Stewart \& Sons, Ltd., 336 U.S. 386, 395-96 (1949).

"The exact words of the opinion are: "[I]f indeed, the Belgian limitation attaches to the right, then nothing in The Titanic [citation omitted] stands in the way of observing that limitation." Id. at 395. It is difficult to determine whether Frankfurter meant for this interpretation to apply only when the foreign limitation is lower than the American, or, to the contrary, to apply whenever the foreign limitation is substantive under the law of the creating state. The latter interpretation would seem to fly in the face of the 1936 amendment to the act. See text accompanying note 54, infra. The former, however, arguably has merit, at least in some situations. See text accompanying note $6 \mathrm{I}$, infra.

${ }^{\circ} I d$. at 396. (Emphasis added.) 
of foreign substantive law; a foreign limitation of liability will be applied if the creating state considers it substantive, absent compelling policy reasons to the contrary. ${ }^{41}$ Where, however, the foreign limitation is higher than the American, then the rule of The Titanic still governs and the American limitation will be applied. ${ }^{42}$ The latter result is reached regardless of whether the foreign limitation is considered as substantive or procedural under foreign law, since according to The Titanic the American act expresses a policy favoring shipping which limits the liability in domestic courts to the maximum provided for by the Limitation of Liability Act. ${ }^{43}$

As there have been no significant decisions on the point since The Norwalk Victory, ${ }^{44}$ the exact state of the law is somewhat uncertain, although it may be as set forth in The Titanic and The Norwalk Victory. Whether this is the most desirable solution to the problem is, however, another question.

\section{Evaluation and Analysis}

The problem of whether to apply American or foreign limitation law to cases with domestic and foreign elements cannot adequately be solved by the substance-procedure dichotomy. ${ }^{45}$ This system, resorted to in The Titanic, enhances certainty and predictability on the surface only; it does not take into account underlying considerations which undoubtedly have an impact on the court's determination. ${ }^{48}$ A more

${ }^{4}$ Cf. GCODRICH, THE CONFLict of LaWs, $\S 9 x$, at 259 ( 3 d ed. 1949). "If the limitation [of amounts recoverable] is created by the state where the cause of action arose, the problem is analogous to the one of damages, and the plaintiff should be barred from recovering more no matter where suit is brought." Ibid.

"See note 29, supra.

${ }^{43}$ This formulation is hypothetical, and has not been recognized in the cases. It is, moreover, subject to the doubt expressed in note 39 , supra, with respect to the faslion in which Frankfurter differentiates between The Titanic and the situation where the limitation under the foreign law is substantive.

" A survey of the cases shows no significant decisions on point relying on either The Titanic or The Norwalk Victory after the decision in The Norwalk Victory. Although The Titanic and The Norwalk Victory have been subsequently cited, the later cases are all distinguishable. See, e.g., Accinanto v. Cosmopolitan Shipping Co., too F. Supp. 826 (D.C. Md. I95I).

${ }^{6}$ Cf. Grant v. McAuliffe, 4x Cal. 2d 859, 264 P.2d 944 (1953). For comment by the judge who wrote the opinion in the Grant case, see Traynor, Is This Conflict Really Necessary?, 37 TExas L. Rev. 657 (x959).

"These underlying considerations may, of course, have an effect on the label selected by the judge. Note, Conflict of Laws: Application of Foreign Remedies, 1961 DuKE L.J. 3 I 6 . 
desirable result would have obtained if Holmes had ascertained the governmental policy evidenced in the Limitation of Liability Act, and then determined whether the situation involving a foreign petitioner on the one hand, and foreign and domestic claimants on the other, was one in which the United States had a legitimate interest in application of that policy. ${ }^{47}$ Though Holmes may have analyzed the problem in this fashion, he couched the opinion in terms of "procedure" and "remedy" thus inducing the lower courts to decide future cases without analysis of the government's interest, or lack of it, in the pertinent situation.

The Limitation of Liability Act was passed primarily to encourage American shipping and to place it on an equal footing with the foreign industry. ${ }^{48}$ The congressional debates fail to reveal any other purpose $^{49}$ than that expressed by Senator Hamlin of Maine, who introduced the bill:

It is an encouragement to our navigating interest all over the land. It is removing some of those liabilities by which every man who is connected with that interest, and is able to respond to the damages that properly belong to him, will do so, and continue in the business.

If then, the only purpose of the act was to protect and encourage American shipping interests, the reasoning of The Titanic seemingly lacks persuasiveness, insofar as it would apply the act to foreign shipping interests. At best it would seem rather imaginative to reason, without more, that American policy would be contravened if American citizens were allowed to recover a greater sum from British shipowners than the American act allows. ${ }^{51}$ This view is, however, myopic. The

\footnotetext{
"For a good statement of the type of analysis suggested in the text, see Currie \& Lieberman, Purchase-Money Mortgages and State Laws: A Study in Conflict of Laws Method, I 960 DuRE L.J. I, at 9.

"See Hughes, Admiralty LaW 304 (1901); McHose, Admiralty Jurisdiction and Limitation of Liability in Single Claim Cases, 22 CALIF. L. REv. 526 (1934). "The statute was enacted by Congress in 1851 for the purpose of encouraging shipbuilding, the investment of money in ships and the employment of ships in commerce." Ibid.

d8 CONG. Globe, 3 Ist Cong., 2d Sess. 715 (1851) [covering 1850-51].

${ }^{\text {Bo }} I d$. at 713-20. [Emphasis added.]

"Iudging from the congressional debates on the act, it can hardly be said that it was originally enacted for the protection of British shipping interests. See text accompanying note 50, supra. For a critical view of The Titanic, see Kuhn, International Aspects of The Titaric case, g AM. J. INTIL L. 336, 342 (IgI5). Moreover, the mere fact that the forum may have a different statutory limitation than the foreign is not enough, standing alone, to justify application of the local law. Herrick v. Minneapolis \& St. L. Ry., 31 Minn. It, 16 N.W. 413 (1883); Note, Limitation of Shipowners Liability in American Courts, 78 U. PA. L. REV. 393, 400. (1930).
} 
labeling of the act as procedural mistakenly leads foreign countries to believe that we have no interest in their disposition of cases involving American shipowners. The procedural classification also compels application of American law despite a complete lack of domestic interest in the controversy other than that the case appears before a local court. ${ }^{52}$

Much of the doubt which surrounds The Titanic has stemmed from the diffculty of discovering the policy Congress originally had in mind with respect to foreign shipowners. The 1936 amendment- "American or foreign"- ${ }^{63}$ should have eliminated this problem: the amendment makes it clear that where there is a domestic interest in the litigation, foreign shipowners are entitled to equal treatment with American shipowners. ${ }^{54}$ The other alternatives available to Congress were: to limit application of the act to American owners; to give the foreign owner the benefit of his home limitation; or to apply the American or foreign act whichever is more restrictive. The first of these alternatives would be shortsighted and would likely invite retaliation against American shipowners in foreign courts. ${ }^{\text {t5 }}$ The second would be too generous ${ }^{56}$ and the third attempts too nice a balance between domestic and foreign interests. ${ }^{57}$ Congress avoided these difficulties by adopting the simpler approach of treating foreign and American shipowners equally. This policy is similar to that of the equal protection clause of the Constitution and may have been inspired by the similarity be-

\footnotetext{
${ }^{82}$ See, e.g., Lauritzen v. Larson, 345 U.S. 571, 591 (1953), where The Titanic is approvingly cited without reference to The Norwalk Victory.

${ }_{\text {ss }}$ Act of June 5, 1936, ch. $521, \S 4283,49$ Stat. 1479.

64 This statement is qualified by the caveat that there must be a domestic interest. Otherwise, there would be no reason for applying domestic law. Where there is such an interest, however, Congress has prescribed an equal treatment policy. Cf. Currie \& Schreter, Unconstitutional Discrimination in the Conflict-of-Laws: Equal Prolection, 28 U. CHI. L. REv. I, II-29 (1960).

${ }^{50}$ It would have been possible for Congress to enact that American, and only American, shipowners could petition for liability in a domestic forum. Such legislation would have provided claimants unlimited recovery in suits against foreign shipowners, but limited recovery against American owners. Such discrimination would invite retaliation by foreign governments. See id. at 22 .

${ }^{86}$ This alternative would, at least in some cases, give foreign owners an advantage over American. This was the very thing Congress originally set out to prevent in the original act. See nn. $48 \& 49$, supra.

${ }^{87}$ The vice of this alternative rests in the complicated manner in which it attempts to" solve an essentially simple problem. The solution selected by Congress is better, but only because it is simpler and more consistent.
} 
tween the nature of the shipping industry and trade between federated political units. ${ }^{58}$

With congressional policy thus defined, there are four possible mixed party situations in which a choice of limitation law problem may arise:

(I) all parties domestic;

(2) domestic shipowner, foreign claimant;

(3) foreign shipowner, domestic claimant; ${ }^{59}$

(4) all parties foreign.

American policy is clear in the first two situations. When all the parties are American, domestic law should be applied, for Congress has expressly subordinated these claimants' interests to that of the shipowner. This is true despite the locality of the incident giving rise to the liability, for Congress could hardly have intended to protect American shipowners only when they are in domestic or international waters. ${ }^{60}$ Domestic law should also be applied where the shipowner, but not the claimant, is American. The domestic interest here is to see that the American owner is given the protection contemplated in the act. This was the situation in The Norwalk Victory, where Frankfurter intimated that in certain cases the foreign limitation law might be applied if it were lower than the American, and in addition, "attached to the right." The argument could be made that the policy of the American act would best be carried out if the limitation providing for lower liability were to be applied. Yet this would seem shortsighted. The application of the lower foreign limitation in this situation discriminates against the foreign claimant. This is evident when it is considered that if the claimant also had been American, the higher domestic limitation probably would have been applied.

When the shipowner is foreign, but the claimants domestic, as in the

${ }^{88}$ Cf. Currie \& Schreter, Unconstitutional Discriminaiton in the Conflict-of-Laws: Equal Protection, 28 U. CH1. L. REv. 1, 22 (1960).

"D This situation is likely to be varied by the presence of both foreign and domestic claimants in a proceeding initiated by a foreign shipowner. See text accompanying note 66, infra.

${ }^{\circ 0}$ Cf. Schmidt v. Driscoll Hotel, Inc., 249 Minn. 376, 82 N.W.2d 365 (I957). Congress was not so much concerned with where the incident happened, as distiuguished from to whom it happened, because their motive was to protect shipowners. It would be difficult to devise any theory which would significantly relate to where the incident occurred. See Currie, Married Women's Contracts: $A$ Study in Conflict-of-Laws Methods, 25 U..CHI. L. REv. 227, 23.6.(1958).' See also text accompanying note 4, supra.

${ }^{\circ 1}$ Black Diamond S.S. Co. v. Robert Stewart \& Sons (The Norwalk Victory), 336 U.S. 386 ( 1949 ). See note 39 , supra. 
third situation, the policy in favor of applying domestic law is also clear. The 1936 amendment shows that Congress intended to treat foreign shipowners equally with American, and this is equally true when application of American law would be detrimental to the foreign owner. ${ }^{02}$ Moreover, the Limitation of Liability Act is the result of balancing of interests and it would be senseless to argue that Congress had no intention of protecting domestic claimants. Since the foreign shipowner would seek to have his liability limited under the foreign act only when it would result in less recovery for the claimant, application of the foreign law would subordinate the interest of the domestic claimant to a greater degree than Congress intended. ${ }^{03}$

When all the parties are foreign, there is no legitimate domestic interest in the controversy and therefore no justification for application of local law per se. ${ }^{84}$ It is in fact possible that the American policy would be to apply the foreign limitation law, for in the opposite caseall parties American, foreign forum-it would be our hope that American law would be applied. The foreign shipowner will not be discriminated against, because he is being treated exactly as he would have been in his home forum. This analysis is, of course, subject to the qualification that the domestic court will apply its own rules and practices to the extent it would be inconvenient or impractical to do otherwise. ${ }^{65}$

For simplicity, the discussion to this point has assumed that all of the claimants were either American or foreign. In practice, however, many situations will arise where both American and foreign claimants will seek to participate in the limitation fund. ${ }^{06}$ If the shipowner is American, then the varied nationalities of the claimants is not relevant; ${ }^{07}$ it is only where the shipowner is foreign that a problem is raised. In the latter situation, there is no difficulty as to the law to be applied to the American claimants; the policy of the limitation law calls for the

${ }^{02}$ Cf. Currie \& Schreter, supra note 58, at 27.

${ }^{63}$ See Currie, supra note 60, at 234.

"Id. at 240 .

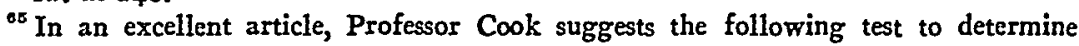
what domestic law should be applied despite general application of foreign law: "How far can the court go in applying the rules taken from the foreign system of law without unduly hindering or inconveniencing itself?" Cook, "Substance" and "Procedure" in the Conflict of Laws, 42 YALE L.J. 333, 344 (1933).

"For example, in the Andrea Doria-Stockholm collision, Time, Aug. 6, 1956, p. 12, both of the vessels were foreign, yet there were many American claimants. See note 59, supra.

${ }^{67}$ See text accompanying note $6 \mathrm{I}$, supra. 
application of domestic law. ${ }^{68}$ There is no such interest in applying domestic law to the foreign claimants. ${ }^{69}$ This dilemma might be resolved by applying domestic law to domestic claimants, and foreign law to foreign claimants. One difficulty with this approach is the possibility of double liability on the part of the shipowner. ${ }^{70}$ Another, and perhaps more serious difficulty, would be the practical problem of devising a fair and manageable system of administering separate trials. An alternative to splitting would be to decide that it would be too complicated, inconvenient and time consuming ${ }^{71}$ to attempt the application of foreign limitations to those claimants in whom there is no domestic interest, and accordingly apply American law by default.

\section{Conclusion}

It is illusory to believe that the substance-procedure dichotomy is the best method of solving the problem of what limitation law to apply where foreign and domestic parties are involved. The governmental interest method of analysis, which rejects the niceties of the traditional "black letter" rule, is a sounder approach. By use of this method, the Limitation of Liability Act is given maximum effectiveness in attaining its avowed purpose of protecting American shipowners where there is a legitimate domestic interest in the litigation.

os See text accompanying note $6_{3}$, supra.

"See text accompanying note 64, supra.

${ }^{70}$ The prospect of multiple liability did not seem to concern Justice Holmes in The Titanic: "We see no absurdity in supposing that if the owner of the Titanic were sued in different countries, each having a different rule regarding the remedy there, the local rule should be applied in each case." 233 U.S. 718, 734 (1914). However, this case was decided before the 1936 amendments to the act, which clarified American policy as being one of nondiscrimination.

To overcome the possibility of multiple recovery would not be easy. To illustrate, a simple case will be assumed: a vessel sank with complete loss of life. This incident happened after the Morro Castle amendments to the Limited Liability Act were enacted, 49 Stat. 960 (1935), 46 U.S.C. $\$ 183$ (b) (1958), providing that culpable shipowners would be liable for loss of life or personal injury in an amount equal to $\$ 60$ per ton, even if the vessel were a total loss. If there were roo claimants, to of whom were domestic, and a 10,000 ton vessel, it would be possible-if these were the only claims-to devise an algebraic formula to accomplish equivalence. For example, $1 / 1$ oth of 10,000 or 1,000 tons could be made available for satisfaction of the shipowner's liability to the domestic claimants. If, in addition to the death claims, there were also cargo claims, salvage, claims by other vessels, etc., a special master could be appointed to make the necessary calculations. It seems apparent, however, that there is a point of diminishing returns involved here. It may well be that the difficulty of finding a convenient method of dealing with this situation is sufficient justification for applying local law. The courts of the forum have an interest, it would seem, in the expeditious settlement of claims.

${ }^{71}$ See the comments by Professor Cook, note 65, supra. 